\title{
Molecular diversity of the invA gene obtained from human and egg samples
}

\author{
Mona Kadry ${ }^{1}$, Sara Mohamed Nader ${ }^{1}$, Sohad M. Dorgham² and Mai M. Kandil ${ }^{2}$
}

1. Department of Zoonoses, Faculty of Veterinary Medicine, Cairo University, Giza 11221, Egypt; 2. Department of Microbiology and Immunology, National Research Centre, Giza 12622, Egypt.

Corresponding author: Sohad M. Dorgham, e-mail: sohad_dorgham@yahoo.com

Co-authors: MK: vet_moony@yahoo.com, SMN: Dr.saranader@yahoo.com,MMK: mai.kandil@hotmail.com Received: 14-01-2019, Accepted: 28-05-2019, Published online: 15-07-2019

doi: 10.14202/vetworld.2019.1033-1038 How to cite this article: Kadry M, Nader SM, Dorgham SM, Kandil MM (2019) Molecular diversity of the invA gene obtained from human and egg samples, Veterinary World, 12(7): 1033-1038.

\begin{abstract}
Background and Aim: Salmonellosis is one of the most common foodborne bacterial diseases in the world. The great majority of Salmonella infections in humans are foodborne with Salmonella enterica and Salmonella Typhimurium accounting for a major part of the problem. The objective of this study was to investigate the presence of inv $A$ gene in strains of Salmonellae isolated from eggs and diarrheal swabs from human cases. In addition, the relationship between invA gene nucleotide sequences from different sources (human stool and egg samples) have been studied through phylogenetic tree.
\end{abstract}

Materials and Methods: One hundred and seventy eggs (eggshell and its contents) and 160 stool swabs samples were collected from four poultry farms and medical hospital in Giza Governorate.

Results: The study reported the presence of two Salmonella strains in eggshell surface with an overall isolation rate of 1.2 and $0 \%$ of the egg content. Salmonella Enteritidis and Salmonella Typhimurium were isolated from eggshell surface with an incidence of $50 \%$ for each strain. Six salmonella strains were isolated from human stool with an incidence of $3.75 \%$; the isolated strains are $S$. Typhimurium, $S$. Enteritidis, Salmonella Virchow, Salmonella Haifa, and Salmonella Kentucky with an incidence of $33.3 \%, 16.6 \%, 16.6 \%, 16.6 \%$, and 16.6\%, respectively. Among eight Salmonella strains, invA gene was detected with percentage of $50 \%$. The phylogenetic analysis of the sequences invA gene, from two isolates included in this study and five isolates retrieved from GenBank showed that sequence from human, layer hens, egg, and water in the same clusters.

Conclusion: Close relation between drinking contaminated water and layer hens and contaminated water is one such source.

Keywords: invA gene, phylogeny, Salmonella.

\section{Introduction}

Salmonella is one of the most important foodborne pathogens which caused food safety hazards for the food industry. Salmonellosis is a critical medical issue and a major challenge worldwide having greater significance in developing countries [1]. The danger of Salmonella may vary between the production systems, caused by components of the husbandry systems affecting disease development and pathogen shedding or differences in the level of resistance to the pathogen [2].

The presence of Salmonella in poultry farms is a major concern for public health [3]. Poultry products, particularly eggs and egg products, are nutritive nourishment of human food. Egg farms and market outlets may be contaminated with Salmonellae at any production stage by horizontal or vertical transmission. Vertical transmission means contamination of egg yolk, albumin, membranes, or eggshells. While in

Copyright: Kadry, et al. Open Access. This article is distributed under the terms of the Creative Commons Attribution 4.0 International License (http://creativecommons.org/licenses/by/4.0/), which permits unrestricted use, distribution, and reproduction in any medium, provided you give appropriate credit to the original author(s) and the source, provide a link to the Creative Commons license, and indicate if changes were made. The Creative Commons Public Domain Dedication waiver (http://creativecommons.org/ publicdomain/zero/1.0/) applies to the data made available in this article, unless otherwise stated. horizontal transmission, disease is penetrated during or after oviposition through the eggshell from the gut or contaminated feces [4]. The cause and the method of the spread of Salmonella spp. between the egg items and the customers should be recognized to influence the illness manage. Moreover, Salmonella spp. contamination may be prevalent in a farm environment. The virulence of Salmonella is linked to a combination of chromosomal and plasmid factors. Different genes such as invA, spv, fimA, and sth are known as major virulence genes accountable for salmonellosis. The chromosomally located invasion gene invA codes for a protein in the inner membrane of bacteria that are necessary for invasion of epithelial cells [5]. The invA sequence of enteric bacteria contains sequences distinctive to the current genus and has been established as an appropriate polymerase chain reaction (PCR) target with potential diagnostic application [6,7]. Conventional methods for the identification of Salmonella are time-consuming and need selective enrichment and plating, followed by biochemical tests. On the other hand, PCR is a rapid and reliable technique for the detection and identification of foodborne pathogens as a complementary to conventional culture [6].

Therefore, our study was designed to investigate the presence of invA gene in Salmonellae strain. 
The phylogenetic tree was used to detect the relationship between the invA gene sequences from different sources (human stool and egg samples).

\section{Materials and Methods}

\section{Ethical approval and informed consents}

The study was conducted according to ethical guidelines approved by Faculty of Veterinary Medicine, Cairo University, Egypt. Stool samples from human were collected after informed consents.

\section{Sample collection}

A total of 170 eggs (eggshell and its contents) from four poultry farms and 160 stool swabs samples from the Medical hospital were collected during the period from April to May 2016 in Giza Governorate.

\section{Isolation and identification of Salmonella strains}

Eggshell surface

A sterile cotton swab, soaked in sterilized normal saline was swabbed on egg surface and immersed in $10 \mathrm{ml}$ normal saline solution followed by transmission to $90 \mathrm{ml}$ of buffered peptone water then incubated at $37^{\circ} \mathrm{C}$ for $18 \mathrm{~h}[8]$.

\section{Egg albumin and yolk}

Samples of egg yolks and egg albumins were examined separately as $5 \mathrm{ml}$ of each sample was mixed with $5 \mathrm{ml}$ of normal saline solution. Afterward, the solution was transferred to $90 \mathrm{ml}$ of buffered peptone water and incubated at $37^{\circ} \mathrm{C}$ for $18 \mathrm{~h}$. Identification of Salmonella: $1 \mathrm{ml}$ pre-enriched sample was added in $10 \mathrm{ml}$ Rappaport-Vassiliadis (RV) medium vortexed and incubated for $24 \pm 2 \mathrm{~h}$ at $42^{\circ} \mathrm{C}$; then, loopful of each RV tube was cultured onto the surface of Xylose-Lysine Deoxycholate (XLD) agar for $24 \mathrm{~h}$ at $37^{\circ} \mathrm{C}$.

\section{The stool samples}

About 2-10 g stool was collected into a sterile leak-proof container (not use preservatives) and then thoroughly coated sterile cotton swab with fecal material then inserted the swab in its sheath and these samples were inoculated aseptically into tubes containing buffer peptone water. About $1 \mathrm{ml}$ pre-enriched sample was added in $10 \mathrm{ml} \mathrm{RV}$ medium vortexed and incubated for $24 \pm 2 \mathrm{~h}$ at $42^{\circ} \mathrm{C}$; then, loopful of each RV tube was cultured onto the surface of XLD agar for $24 \mathrm{~h}$ at $37^{\circ} \mathrm{C}$ [9]. Typical Salmonella colonies were subjected to a series of biochemical, serological, and molecular tests for the identification of Salmonella spp.

\section{Biochemical identification}

Suspected colonies were identified using chemical tests, including Gram staining, indole, methyl red, Voges-Proskauer, citrate utilization, triple sugar iron, and lysine decarboxylation [10].

\section{Serological identification}

Serotyping of isolates was done in serogroup level by a standard agglutination test using $\mathrm{O}$ and $\mathrm{H}$ antisera (Difco, USA). It was performed by the central public health laboratories.

\section{Molecular detection of invA gene}

\section{DNA extraction}

The DNA of Salmonella strains was extracted using the boiling method [11]. The reaction mixture consisted of $25 \mu \mathrm{l}$ Platinum $^{\text {TM }}$ Hot Start PCR Master Mix $\left(\right.$ Invitrogen $^{\mathrm{TM}}$ ), $1 \mu \mathrm{l}$ DNA extract, $0.5 \mu 1$ of each primer in the concentration of $20 \mathrm{pmol}$, and nuclease-free water up to $50 \mu$. The PCR for inv $A$ gene-specific oligonucleotide primers for $i n v A$ gene is described in Table-1 [12]. Temperature and time conditions of the primers during PCR are shown in Table-2.

The PCR products were resolved by electrophoresis on $1.5 \%(\mathrm{wt} / \mathrm{vol})$ agarose gels (QIAGEN, Hombrechtikon, Switzerland).

\section{Sequence analysis for invA gene}

About $20 \mathrm{uL}$ from each primer were aliquoted into thin-wall PCR tubes. Tubes were sent by mail to be sequenced at laboratory technology; then, the DNA sequencer was used to conduct sequencing. The whole experimental process was monitored through the Laboratory Information Management System. The results of sequencing were analyzed by BLAST web tool of the Genbank (NCBI). We performed the alignment by Multalin interface and for the construction of the phylogenetic tree by use from www.phylogeny.fr "one click mode."

\section{Results}

\section{Isolation and identification of Salmonella strains}

From tested 170 eggs (eggshell and its contents) using biochemical and serological identification, only two Salmonella strains ( $S$. Enteritidis and $S$. Typhimurium) were isolated from eggshell surface and also six Salmonella strains were isolated from 160 stool swabs samples with an incidence of 3.75\%; the most prevalent serovar was $S$. Typhimurium (33.3\%) followed by $16.6 \%$ of each $S$. Enteritidis, Salmonella Virchow, Salmonella Haifa, and Salmonella Kentucky.

\section{Molecular detection of invA gene}

The PCR assay was carried out in this study for the detection of Salmonella invasion gene (invA) in eight Salmonella isolates and the result revealed that $50 \%$ were positive for invA gene in both egg (S. Typhimurium) and human ( $S$. Virchow and $S$. Kentucky) isolates.

\section{Sequence analysis and phylogenetic tree}

The authors illustrated in this study a robust phylogeny of Salmonella subspecies using the sequences of invasion (invA) gene, from two isolates with accession numbers (MG001904- MG001905) included in this study and five isolates retrieved from GenBank. Analysis of these sequences showed that the sequences included in this study (human and egg strain) have polytomy which placed in the same clusters with two 
strain retrieved from GenBank (layer hen and water strain) while the other three sequences retrieved from GenBank form a sole different cluster.

\section{Discussion}

Salmonella is an important cause of foodborne (alimentary) health problems in humans [13]. Contamination of eggshell by Salmonella spp. can happen through fecal material, insects, and feed or even through transportation, storage, or during handling. Our study revealed that an overall isolation rate of Salmonella in eggshell surface and egg content were $1.2 \%$ and $0 \%$ respectively as shown in Table-3 , this may be due to fecal material contamination. Similar observations were stated by Davies and Breslin [14]. On the other side, the eggshell surface contamination increases the risk of egg contents contamination by penetration through egg surface cracks [15]. According to Table-3, $S$. Enteritidis and $S$. Typhimurium were isolated from egg samples (the most common serotype among Salmonella isolates), this finding supported by Edema and Atayese [16] who mentioned that hen eggs have become a principal source of $S$. Enteritidis and $S$. Typhimurium since those serotypes can colonize the ovarian tissue of hens, and in this way, it will be available inside the content of intact shell eggs.In addition to that, Salmonella spp. have ability to invade the cells of the follicles before ovulation and multiply themselves after $2 \mathrm{~h}$ of infection [12]. Mwansa et al. [17] reported that $S$. Typhimurium is the predominant Salmonella serovars isolated from human patients. There is a growing concern about human infections caused by other serovars such as $S$. Virchow which has higher abilities than other serovars to cause invasive salmonellosis; furthermore, $S$. Kentucky represents one of the non-typhoidal types of Salmonella species that microbiologists and public health professionals encounter from time to time. What makes $S$. Kentucky stand out and explains its public health importance is that this infectious agent has managed to develop resistance to some antibiotics. Hence, it's tougher to treat [18]. Zou et al. [19] reported that $S$. Enteritidis has been most frequently involved in human salmonellosis outbreaks. According to CDC, $S$. Enteritidis was confirmed to be on the top of the laboratory - human Salmonella infections reports [20,21]. Although potentially all livestock can be infected with Salmonella species, contaminated poultry meat and eggs may be the main source of Salmonella infection for humans, especially where $S$. Enteritidis is implicated, human infections can be traced back to eggs and poultry meat [22]. From this result, it is suggested that there is a strong relationship between cases of Salmonella infection related to human illness and Salmonella species positive in poultry meat and so this explanation is agreed with that stated by Centers for Disease Control and Prevention [23]. More than $70 \%$ of human salmonellosis has been attributed to the consumption of contaminated chicken meat or egg. PCR has become a powerful tool for the detection of pathogens in food, especially Salmonella in the past decade [24]. Furthermore, the detection of Salmonella is rapidly and accurately due to the primer sequences that are selected from the gene invA. The inv $A$ gene considered to be the international standard for the identification of salmonellosis, in addition

Table-1: Primer sequences for invA gene.

\begin{tabular}{llcr}
\hline Target gene & Primer sequence & Size of amplified product & Reference \\
\hline InvA & GTGAAATATCGCCACGTTCGGGCAA & $284 \mathrm{BP}$ & {$[12]$} \\
& TCATCGCACCGTCAAAGGAACC & & \\
\hline
\end{tabular}

Table-2: PCR cycling conditions.

\begin{tabular}{lccccc}
\hline Initial denaturation & Denaturation & Annealing & Extension & Final extension & Number of cycles \\
\hline $95^{\circ} \mathrm{C}$ & $95^{\circ} \mathrm{C}$ & $58^{\circ} \mathrm{C}$ & $72^{\circ} \mathrm{C}$ & $72^{\circ} \mathrm{C}$ & 35 \\
$10 \mathrm{~min}$ & $1 \mathrm{~min}$ & $1 \mathrm{~min}$ & $1 \mathrm{~min}$ & $10 \mathrm{~min}$ & \\
\hline
\end{tabular}

Table-3: The incidence of isolation and serological identification of Salmonella strains.

\begin{tabular}{|c|c|c|c|c|}
\hline \multirow[t]{2}{*}{ Source of samples } & \multirow[t]{2}{*}{ Number of examined samples } & \multirow{2}{*}{$\begin{array}{c}\text { Salmonellae isolates } \\
\mathrm{n}(\%)\end{array}$} & \multicolumn{2}{|c|}{ Serotyping } \\
\hline & & & Type & n (\%) \\
\hline Eggshell surface & 170 & $2(1.2)$ & $\begin{array}{l}\text { S. Enteritidis } \\
\text { S. Typhimurium }\end{array}$ & $\begin{array}{l}1(50) \\
1(50)\end{array}$ \\
\hline Egg content & 170 & $0(0)$ & - & - \\
\hline Stool & 160 & $6(3.75)$ & $\begin{array}{l}\text { S. Typhimurium } \\
\text { S. Enteritidis } \\
\text { S. Virchow } \\
\text { S. Haifa } \\
\text { S. Kentucky }\end{array}$ & $\begin{array}{l}2(33.3) \\
1(16.6) \\
1(16.6) \\
1(16.6) \\
1(16.6)\end{array}$ \\
\hline
\end{tabular}

S. Typhimurium=Salmonella Typhimurium, S. Enteritidis=Salmonella Enteritidis, S. Virchow=Salmonella Virchow, Salmonella Haifa=S. Haifa, S. Kentucky=Salmonella Kentucky 


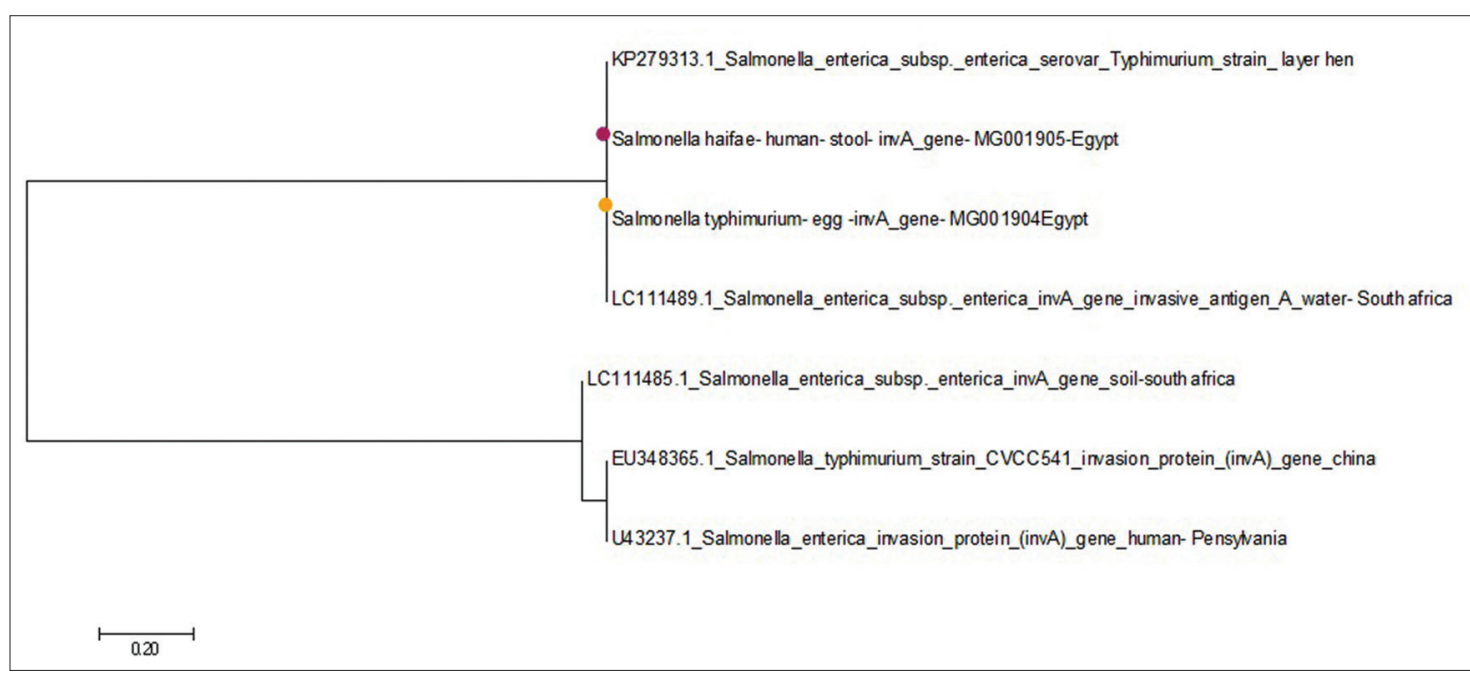

Figure-1: A phylogeny of Salmonella subspecies using the sequences of invasion invA gene.

to being introduced as effective, rapid, and accurate method for the detection of Salmonella in foods of animal origin [25]. The presence of invA gene is referred to its ability for invasion of cells, having the capacity to invade and survive in macrophages [26]. The World Health Organization [27] mentioned that $S$. Typhimurium and $S$. Enteritidis are the most significant serovars harboring the virulence invA gene causing salmonellosis globally. According to our results (Table-4), among eight Salmonella strains, invA gene was detected $50 \%$, this results fully agreed with Indu and Kashmiri [28] who mentioned that invA gene was present in 22 isolates (55\%) from 40 Salmonella isolates from poultry meat samples. Our results disagreed with Sheila et al. [29] who stated that of 32 samples, four samples of Salmonella which isolated from milkfish carried invA gene with a length of $284 \mathrm{bp}$, while 28 samples did not show the target band. The current study explained the absence of inv $A$ gene in certain Salmonella strains because they are not invasive or may have other invasive mechanisms; this indication supported by Malorny et al. [25].

\section{Analysis of phylogenetic tree}

Bacteria belonging to the genus Salmonella are a very important reason for human food poisoning. In certain parts of the world, Salmonella is also an important cause of disease in poultry. Salmonella serotypes can be introduced into poultry flocks from many different sources which can carry Salmonella either at the farm level or in the processing plants. We illustrated in this study a robust phylogeny (Figure-1) of Salmonella subspecies using the sequences of invasion (invA) gene, from two isolates included in this study and five isolates retrieved from GenBank. Analysis of these sequences showed that sequence from human, layer hens, egg, and water in the same clusters which refer to the close relation between drinking contaminated water and layer hens and contaminated water is one such source, which returns into the contamination of eggshell and finally leads to
Table-4: Detection of invA gene from the positive serotyping.

\begin{tabular}{lll}
\hline $\begin{array}{l}\text { Source of } \\
\text { samples }\end{array}$ & Serotypes & Presence of InvA gene \\
\hline Eggshell & S. Enteritidis & Negative \\
surface & S. Typhimurium & Positive \\
Stool & S. Typhimurium & (1 out of 2) \\
& S. Enteritidis & Positive \\
& S. Virchow & Negative \\
& S. Haifa & Positive \\
& S. Kentucky & Negative \\
\hline
\end{tabular}

S. Typhimurium=Salmonella Typhimurium, S. Enteritidis=Salmonella Enteritidis,

S. Virchow=Salmonella Virchow, Salmonella

Haifa=S. Haifa, Salmonella Kentucky=S. Kentucky

human infection [30]. The other cluster explains the use of fecal matter of animals and poultry in fertilizing the ground, leading to soil contamination which may also reflect on shell egg contamination on the farm [31]. According to our results, it is noted that chicken and human are an important source of infection to each other. This result was supported by Nawar and Khedr [32] who reported that Salmonellae can be transmitted to humans through dealing with chicken meat and/or consumption of uncooked meat and eggs.

\section{Conclusion}

Finally, from work done here, we have to advise; application of strict biosecurity will be a need on the farm. Very strict restrictions measures on personnel and equipment movement should be taken. Routine checks for the presence of Salmonella species should be often undertaken. Within chicken meat processing plants, there would be a number of steps taken (e.g., water chlorination, correct temperature controls) to ensure that contamination is under control. The study concluded that eggs are representing a source of infection with Salmonella in the absence of exposure to sufficient heat during the process of cooking and, therefore, should beware of desserts or foods containing raw eggs. In addition to that, personal hygiene of 
food handlers must be taken in consideration; food areas should be kept clean and regularly sanitized to reduce the risks of food poisoning outbreaks and finally, make people aware of the dangers of foods that contain undercooked eggs and egg products.

\section{Authors' Contributions}

SMD and MMK performed bacterial isolation and identification. MK, SMN finished PCR and analysis of phylogenetic tree. All authors participated in draft and revision of the manuscript. All authors read and approved the final manuscript.

\section{Acknowledgments}

The authors are thankful to the Department of Zoonoses, Faculty of Veterinary Medicine, Cairo University, Egypt for providing necessary facilities for this study. The authors did not receive any fund for this study.

\section{Competing Interests} interests.

The authors declare that they have no competing

\section{Publisher's Note}

Veterinary World remains neutral with regard to jurisdictional claims in published institutional affiliation.

\section{References}

1. Adel El-Sebay, N., Abu Shady, H.M., El-Zeedy, S.A. and Samy, A.A. (2017) InvA gene sequencing of Salmonella Typhimurium isolated from Egyptian poultry. Asian J. Sci., 10(3): 194-202.

2. Zheng, D.M., Bonde, M. and Sorensen, J.T. (2007) Associations between the proportion of Salmonella seropositive slaughter pigs and the presence of herd level risk factors for introduction and transmission of Salmonella in 34 Danish organics, outdoor (non-organic) and indoor finishing-pig farms. Livest. Sci., 106:189-199.

3. Joseph, A.A.O., Samson, E.I., Onyemocho, A., Idowu, O., Fagbamila, J.C.I. and Ifeanyi, S.S. (2016) Isolation and polymerase chain reaction detection of virulence invA gene in Salmonella spp. from poultry farms in Jos, Nigeria. J. Med. Trop., 18(2): 98102.

4. Mir-Hassan, M., Saber, E., Fahimeh, B.A., Ehsan, M. and Taghi, Z.S. (2015) Detection of Salmonella spp. in commercial eggs in Iran. Iran. J. Microbiol., 7(1): 50-54.

5. Sharma, I. and Das, K. (2016) Detection of invA gene in isolated Salmonella from marketed poultry meat by PCR assay. J. Food Process. Technol., 7(3): 564.

6. Mohamed, K. (2013) Detection of virulence gene (invA) in Salmonella isolated from meat and poultry products. Int. J. Genet., 3(2): 7-12.

7. Shanmugasamy, M., Velayutham, T. and Rajeswar, J. (2011) InvA gene-specific PCR for detection of Salmonella from broilers. Vet. World, 4(12): 562-564.

8. Singh, S., Yadav, A.S., Singh, S.M. and Bharti, P. (2010) Prevalence of Salmonella in chicken eggs collected from poultry farms and marketing channels and their antimicrobial resistance. Food Res. Int., 43(8): 2027-2030.

9. Ruiz, J., Sempere, M.A., Varela, M.C. and Gomez, J. (1992) Modification of the methodology of stool culture for Salmonella detection. J. Clin. Microbiol., 30(2): 525-526.

10. Atek, A.K., Andrew, B., Tonny, J.O., Joel, B. and
Samuel, M. (2017) Molecular characterization of Salmonella from human and animal origins in Uganda. Int. J. Bacteriol., Volume 2017, Article ID 4604789, 9 pages.

11. Murugkar, H.V., Rahman, H. and Dutta, P.K. (2003) Distribution of virulence genes in Salmonella serovars isolated from man and animals. Indian J. Med. Res., 117: 66-70.

12. Kaushik, P., Anjay. and Dayal, S. (2014) Rapid PCR detection of Salmonella from stool samples. J. Vet. Public Health, 12(2): 71-74.

13. Smith, R.P., Clough, H.E. and Cook, A.J. (2010) Analysis of meat juice ELISA results and questionnaire data to investigate farm-level risk factors for Salmonella infection in UK pigs. Zoonoses Public Health, 57(1): 39-48.

14. Davies, R. and Breslin, M. (2004) Observations on Salmonella contamination of eggs from infected commercial laying flocks where vaccination for Salmonella enterica serovar Enteritidis had been used. Avian Pathol., 33(2): 133-144.

15. Messens, W., Grijspeerdt, K. and Herman, L. (2006) Eggshell penetration of hen's eggs by Salmonella enterica serovar Enteritidis upon various storage conditions. Br. Poult. Sci., 47(5): 554-560.

16. Edema, M. and Atayese, A.O. (2006) Bacteriological quality of cracked eggs sold for consumption in Abeokuta, Nigeria. Int. J. Poult. Sci., 5(8): 772-775.

17. Mwansa, J., Mutela, K., Zulu, I., Amadiand, B. and Kelly, P. (2002) Antimicrobial sensitivity in Enterobacteriaceae from AIDS patients, Zambia. Emerg. Infect. Dis., 8(5): 92-93.

18. Mulvey, M.R., Boyd, D.A., Finley, A.R., Fakharuddin, K., Langner, S., Allen, V., Ang, L., Bekal, S., El Bailey, S., Haldane, D., Hoang, L., Horsman, G., Louis, M., Robberts, L. and Wylie, J. (2003) Ciprofloxacinresistant Salmonella enterica serovar Kentucky in Canada. Emerg. Infect. Dis., 19(6): 999-1001.

19. Zou, M., Keelara, S. and Thakur, S. (2012) Molecular characterization of Salmonella enterica serotype Enteritidis isolates from humans by antimicrobial resistance, virulence genes, and pulsed-field gel electrophoresis. Food Borne Pathog. Dis., 9(3): 232-238.

20. Centers for Disease Control and Prevention. (2017a) Foodborne Diseases Active Surveillance Network (Food Net), 2009 Surveillance Report. Available from: https:// www.cdc.gov/food net/PDFs/FoodNetAR2009 FINAL. pdf. Last accessed on 15-06-2018.

21. Centers for Disease Control and Prevention. (2017b) Foodborne Diseases Active Surveillance Network (Food Net). Food Net 2015 Surveillance Report (Final Data). Available from: https://www.cdc.gov/foodnet/pdfs/ FoodNet-Annual-Report-2015-508c.pdf. Last accessed on 21-05-2019.

22. Plummer, R.A.S., Blissett, S.J. and Dodd, C.E.R. (1995) Salmonella contamination of retail problems. Microb. Infect., 3(8): 237-247.

23. Centers for Disease Control and Prevention. (2013) Available from: http://wwwn.cdc.gov/foodborneoutbreaks/ Default.aspx. Last accessed on 18-05-2019.

24. Awasthi, G., Malik, T., Swarupand, A. and Awasthi, D.K. (2016) Prevalence of Salmonella in food samples of Dehradun region. Int. J. Curr. Adv. Res., 5(7): 1053-1057.

25. Malorny, B., Hoorfar, J., Bunge, C. and Helmuth, R. (2003) Multicenter validation of the analytical accuracy of Salmonella PCR: Towards an international standard. Appl. Environ. Microbiol., 69(1): 290-296.

26. Gole, V.C., Chousalkar, K.K. and Roberts, J.R. (2013) Survey of Enterobacteriaceae contamination of table eggs collected from layer flocks in Australia. Int. J. Food Microbiol., 164(2-3): 161-165.

27. World Health Organization. (2005) Global Salm-Surv Progress Report (2000-2005): Building Capacity for Laboratory-based Foodborne Disease Surveillance and Outbreak Detection and Response. World Health Organization, Geneva. 
28. Indu, S. and Kashmiri, D. (2016) Detection of invA gene in isolated Salmonella from marketed poultry meat by PCR assay. J. Food Process. Technol., 7(3): 1-3.

29. Sheila, M.Y., Reina, P.R., Freshinta, J.W. and Mustofa, H.E. (2019) Detection of InvA gene of Salmonella from milkfish (Chanos chanos) at Sidoarjo wet fish market, Indonesia, using polymerase chain reaction technique. Vet. World, 12(1): 170-175.

30. Whiley, H. and Ross, K. (2015) Salmonella and eggs: From production to plate. Int. J. Environ. Res. Public Health, 12(3): 2543-2556.

31. Séraphin, C.A., Joël, H., Euloge, K.A., Hervé, S. and Romain, G. (2016) Vegetable contamination by the fecal bacteria of poultry manure: Case study of gardening sites in Southern Benin. Int. J. Food Sci., 2016(2): 1-8.

32. Nawar, E.M. and Khedr, A.M. (2014) Molecular studies on Salmonella species isolated from chicken. Alex. J. Vet. Sci., 43(1): 58-64.

$* * * * * * * *$ 